\title{
前庭感覚器の $\mathrm{SM}$ 括よび $\mathrm{KM}$ 中毒の病理学的研究
}

\author{
東北大学医部耳鼻咽喉科学教室 (主任：片桐主一教授) およびドッセルドル \\ フ大学医学部耳鼻咽喉科学教室 (主任 : A. Meyer zum Gottesberge 教授) \\ 綿貫幸咅䇂
}

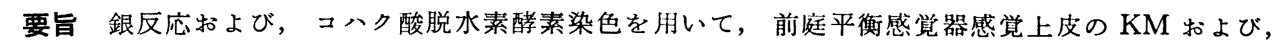
SM による病理变化椂式が, 光学顕微鏡により, 取出し標本で観察された。前庭平衡感覚器感覚上皮に 対する毒性は, $\mathrm{SM} か ゙ \mathrm{KM}$ ょりる強い。感覚器官別では, 半規管膨大部稜飞扰いて最も障害が強く, 次 飞卵形のラ, 球形のラの順であつた。膨大部棱感営上皮は, 中心部と辺縁部と飞分けられ，中心部か辺 縁部よりも障害されやすい，同一部位では，I 型細胞が II 型細胞より脱落するのが早いが，中心部の II 型細胞の多くは，辺縁部のI 型細胞より先に脱落するのがみられた。球形のラおよび, 卵形のラ感敩上 皮では, Striola の障害が最も早い. Striola の中で大きな細胞表面を持つI 型練胞が最初飞脱落するの がみられ，II型細胞では，やはり Striola の中で大きな細胞表面を持つるのが，他の II 型細胞より早く 脱落するが，周辺部のII型細胞と同様小さな細胞表面をもつII型細胞に関しては，Striola と，その他の 周辺部とで著明な差がみられなかつた。I 型およびII 型細胞とで障害に差がある原因に閣して文献的に 考察し, 新しくI 型細胞の形態学的脆弱性が強調された。

\section{緒 言}

ストレプトマイシン $(\mathrm{SM})$ および，カナマイシン $(\mathrm{KM})$ 等の, アミノグルコシード系抗生物質の大量ある いは, 長期投与により, 内耳の感覚器が, コルチ器およ び前庭感覚器で差が認められるものの, 多かれ少なかれ 障害を受けることは, 多くの臨床例および, 動物実験で 認められている. 前庭感覚器における感覚上皮構造は, コルチ器におけるほど, 正確な規則性を有しないが, 感 覚上皮全体を鳥㒈し, 障害された感覚上皮を, 正常のそ れと批較検討することは容易である。音響あるいは，抗 生物質等の障害によるコルチ器の感覚細胞の消失を, 全 体から見た一つの様式として捕える方法として, Engström等 (1966) 1 により, コルチ器の表面取出し 標本 (Surface Preapation) が最近再認識され, 多大の成果を もたらしたが, 前庭感覚器においても, Lindeman $(1969)^{2)}$, Winter (1969) ${ }^{3)}$ 等によりこの方法が応用され 新しい観点から前庭感覚上皮の病理変化が様式としてと らえられ，成果をあげつつある. Lindeman (1969) 主として位相差顕微鏡による取出し標本の観察により, $\mathrm{SM}$ および $\mathrm{KM}$ による前庭感覚器の障害を記載している が, 本研究においては, 最近, 前庭感覚器の取出し標本 に応用され成功をおさめている銀反応(Watanuki 19685),

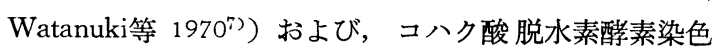
(Barka \& Anderson 19637)) を用い, より明瞭に, SM
およびKMによる前庭感覚器官の障害様式が観察できた ので報告する.

\section{実験材料および方法}

約 $300 \mathrm{~g}$ の正常, 有色モルモット48匹が 4 つの群に分け て用いられた. 硫酸ストレプトマイシン $(250 \mathrm{mg} / \mathrm{kg})$ を 隔日に 4 週間および， 8 週間腹腔内に注射した 2 群. お よび, 硫酸カナマイシン $(250 \mathrm{mg} / \mathrm{kg})$ を隔日に 4 週間お よび, 8 週間腹腔内に注射した 2 群の合計 4 群に分けて 実験を行なつた. 最後の注射後, 約 2 週間で動物を断頭 し，ただちに側頭骨を取出す. 実体顕微鏡下に鐙骨をは ずし，周囲の骨壁を強固な針を用いて，できるだけ卵形 のうおよび, 三半規管を露出するようにする. 数秒間蒸 溜水中に入れて卵形のう，球形のうおよび，三半規管膨 大部を破つた後, ただちに $0.2 \%$ 硝酸銀溶液中に浸し, 冷暗所に約 2 分間放置する. 数秒間, 蒸溜水で再 び 洗 い，10\%ホルマリン液に投じ，24時間以上，螢光燈の下 か，日中ならば，直射日光のあたらない空端にて固定す る. コハク酸脱水素酵素染色は, 次のごとく行なつた. 取出した側頭骨の鐙骨を取りはずしたのち，周囲の骨壁 をできるだけ削り取り, 微細なピンセットを用いて, 卵 形のうおよび，球形のう膜様壁を破る．下記の反応溶液 を, 注射器にて, 卵形のうおよび, 球形のら破断部から 強制的に注入し，三半規管を灌流したのち， $37^{\circ} \mathrm{C} に て$ 約 30分間反応させる. 反応液の組成は次のごとくである. 
コハク酸ナトリウム $, 0.06 \mathrm{M}, 1.0 \mathrm{ml}$, ニトロブルーテト ラゾリウム， $0.2 \%, 2.5 \mathrm{ml}$, リン酸緩衝液, $0.2 \mathrm{M}(\mathrm{pH}$ 7.4), $1.0 \mathrm{ml}$, リンゲル液, $0.5 \mathrm{ml}$. 反応終了後, $10 \%$ 木 ルマリンにて24時間以上の固定を行なつた. 取出し標本 の作製は, 実体顕微鏡下に, 水中にて行な5. 耳石器官 では，水流にて，耳石を耳石膜ごと洗い流したのち，半 規管膨大部では，クプラはすでに反応過程で流出してい るから，そのまま微細な針を用いて，感覚上皮を下部の 支持組織から剥離し，ピペットですくい取り，グリセリ ン封入下に光学顕微鏡による観察が行なわれた.

\section{結果}

感覚細胞の消失のみが見られ，支持細胞の消失はみら れなかつた. SMおよび KMによる前庭感覚上皮の障害 を, 同一投与量で比較すると, 各動物により障害の程度 を多少異にするが，一般に感覚細胞の脱落は，KM より もSMによつて多くみられた. 各感覚上皮の障害を, 感 覚器べつに比較すると, 半規管膨大部稜において最も強 い障害がみられ，次に卵形のう Macula, 球形のう Macula の順であつた. 腹腔内投与および, 局所投与ともに同様 の感鸴器別障害が認められた. 半規管膨大部稜感覚上皮 では, 感覚上皮中心部において障害が最も強かつた. 最 初に脱落する感覚細胞は, 感覚上皮中心部で共通神経杯 をもつた細胞表面のより大きな I 型細胞であり, 次に, 一般の I 型細胞, 次いでII 型細胞であつた。一般に, 前 庭感覚器感覚上皮においては，I 型細胞が，II 型細胞よ り $\mathrm{SM}$ および，KMによる障害に弱いが，膨大部稜感覚 上皮においては，中心部の I型細胞の多くは，辺縁部の I 型細胞より先に脱落するのがみられた. しかし, 少数 の II 型細胞は, 大多数の I 型細胞が辺緩部で消失して も,なお中心部に存在するのがみられた. 脱落した感覚 細胞は, それを取囲む数個の支持細胞が肥大してその間 隙を補修するのがみられた. 感覚細胞を広範囲に失つた 部分の感覚上皮は, 支持細胞のみから成る屚平ないし, 立方上皮を形成しているのが観察された。卵形のうおよ び，球形のう感覚上皮の場合には，それぞれの，ほぼ中 心線を形成する Striola の部分において, 大きな細胞表 面を有する I 型細胞が，その他の周辺部の I 型細胞より 早く脱落するのがみられた.その中でも，共通神経杯をも つI 型細胞が最も先に脱落するのが観察された．卵形の うおよび, 球形のう感覚上皮の全体において，I 型細胞 の脱落が，几型細胞の脱落より早く認められた. Striola における II 型細胞は, 比較的障害に対して強く, 周辺部 の I 型細胞が脱落するまで存在する場合が 多かつた.
Striola の消失は，I 型細胞が全て脱落し，II 型細胞のほ ぼ半分以上が脱落した場合に観察され, 球形のら感覚上 皮では, 前庭神経上枝からくる Voit 神経 (Voit 19078) の支配をらける前上部（鎌状の突出部）において最も早 い. 脱落した感覚細胞によつて生じる感覚上皮の間隙 は，その周囲の支持細胞が肥大することによつて補修さ れ, 感覚細胞を失つた感覚上皮は, 膨大部稜感覚上皮の 場合と同様, 高さを減じた立方上皮を形成するのが観察 された。

\section{考按}

銀反応 (Watanuki 19685), Watanuki 等 $1970^{6)}$ ) を前 庭感覚上皮の染色に応用し, その取出し標本を, 光学顕 微鏡によつて観察すると, 感覚細胞表面のクチワラ層の 下部に焦点を合わせることにより，フラスコ型 I 型細胞 頸部の小さな円と，円柱型 II 型細胞の大きな円とを区別 することができる，さらに，感覚毛を含む細胞表面をよ く観察すると，I 型細胞表面が，II 型細胞表面よりも濃 染されているのを認めることができる．この光による銀 イオン還元反応が， I 型細胞表面で II 型細胞表面より強 く行なわれることは, 細胞表面の化学的構成要素が, I 型および， II 型細胞で，量あるいは，質において異なる ことを意味し，細胞表面とクプラあるいは，耳石膜との 間に生ずる電位が，同一刺激に対して，I 型細胞と II 型 細胞で異なることを示唆するものであるが，I 型細胞と II 型細胞を取出し標本で，広範囲にその正確な分布を知 る方法として極めて有利な方法である. 本研究において は，上記二つの方法によつて I 型細胞と II 型細胞の同定 を行なつた．アミノグリコシード系抗生物質が, 聴器の みでなく, 末梢平衡器にも毒性を有することは多数の文 献にみられる (ストレプトマイシン. Hawkins 1947'9), Hawkins \& Lurie 195210), Winston 等 1948 ${ }^{11}$, Causse

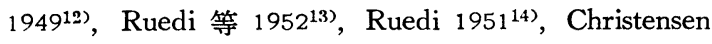

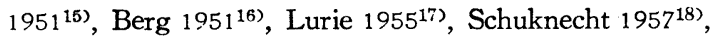
Mcgee \& Olszewski 1962 ${ }^{19)}$, Wersäll \& Hawkins 196200), Duvall \& Wersäll 196421), Spoendlin 1966'2), Igarashi 等 196623), Nagaba 196824), Lange 196822)等. カナマイ シン. Farkashidy 等 19632(5), Lindeman 19694), バイオ マイシン. Kanda \& Igarashi 199928)). これらの多く の報告には, 切片標本のみの観察により, 半規管膨大部 稜感覚上皮においては，その先端部あるいは，頂上部が 斜面部より障害されやすいと記載されている. 最近, Lindeman (1969)4) によつて, 前庭感覚上皮の取出し標 本による病理学的研究が行なわれ，ストレプトマイシン 
および, カナマイシンによる半規管膨大部稜感覚上皮の 変性に関しては，今まで先端部あるいは，頂上部の中に 含まれる部分でも，両端部つまり，半月状面に近い部分 は，斜面部と同様，障害されにくいことを報告し，半規 管膨大部稜感覚上皮を中心部と周辺部に分けて障害の差 を述べている. 本研究においても，二つの異なる染色 法, つまり銀反応および，コハク酸脱水素酵素染色を用 いた取出し標本の観察により， Lindeman $(1966)^{4)}$ の報 告を確認することができた. 球形のうおよび, 卵形のう 感覚上皮のストレプトマイシンおよび, カナマイシンに よる障害が地域的に差があることに関しては, 同じく Lindeman $(1969)^{4)}$ により，感覚上皮の中で Striola (Werner 1933) 28) が，その他の周辺部より，障害されや すいと記載されている. 本研究によれば, Striolaにおい て大きな細胞表面を持つ I 型および， II 型細胞に関する かぎり, 他の周辺部の I 型および, II 型細胞より弱いこ とが確認されたが，周辺部の細胞と同様小さな細胞表面 を有する, 小数のII型細胞では, Striola および, その他の 周辺部で著明な差がみられなかつた。 コハク酸脱水素酵 素染色により，Striolaにおいて大きな細胞表面を持つ幾 覚細胞は濃染され, 感覚上皮全体の取出し標本で, Striola の部分が明膫に区別できるが，Striolaにおいて大きな細 胞表面を持つ I 型および, II 型感覚細胞が脱落し, 周辺 部の II 型細胞の約 $1 / 2 か ゙$ 脱落した場合には, Striola の存在 を認めることができなくなる．この Striola の消失は, 卵形のうでは, 部位的な差異を認めなかつたが, 球形の らでは部位的に異なり, Voit 神経支配の Macula 前上部 （球形のう感覚上皮の鎌状突出部）において, 他の部 分 よりも早く消失するのが観察された．この部位的な差が どのような意味を有するか不明であるが, 球形のう感覚 上皮は, 部位により, 機能的に異なる可能性を有するこ とが示唆される。一般に, 聴器に毒性を有する抗生物質 は, 前庭平衡器感覚上皮を障害する場合, I 型細胞が II 型細胞より障害されやすいとされている. Wersäll おょ び Hawkins (1962) 20) は猫内耳の膨大部稜および, 卵形 のう感覚上皮において観察し, Spoendlin (1966)221は, 同じく猫内耳の卵形の卵形のう感覚上皮を観察して, ス トレプトマイシンの前庭平衡感賞路への障害は，I 型細 胞において， II 型細胞より強いと報告し， Lindeman $(1969)^{4)}$ は最近, モルモットの全ての前庭平衡感覚器の ストレプトマイシンおよび, カナマイシン障害でこれを 再確認している，さらに，Kanda および Igarashi(1969) 27)はバイオマイシンの球形のうおよび, 膨大部稜感覚上
皮への毒性を，猫および，猿で観察し，同様の結果を得 ている.しかし Duvall および Wersäll (1964) ${ }^{21}$ はモ ルモットで実験し， I 型とII 型でストレプトマイシンの 毒性に差異がないと述べている，本研究においては，前 庭平衡感覚器いずれの場合にも, 同一部位においては, I 型細胞が， II 型細胞より障害されやすいことが再確認 された.ただし, 膨大部棱感覚上皮は, 中心部と周辺部 とに区別され (Lindeman 1969²), 中心部の II 型細胞の 多くは，周辺部のI 型細胞より障害されやすいことが認 められた．抗生物質による障害が，I 型細胞において， II 型細胞より強いことに関しては, 諸種の理由があげら れている. I 型細胞は, 系統発生学的に II 型細胞より新 しく, より分化しているので，抗生物質の代謝障害作用 に対して，抵抗力が弱いとする意見がある（Wersäll \& Hawkins 1962 2J), Spoendlin 196622)). しかし, Lindeman $(1969)^{4)}$ は, 抗生物質の組織に対する特異性を重視 している.ここで，I型および， II 型細胞の形態学的な 特徴に注目してみると，I 型細胞は細胞体のほとんどが 神経杯によつて包まれ，隣接支持細胞とはクチクラ下部 の，ほんの一部で接触しているにすぎない，一方，II型 細胞は, 細胞体のほとんどが隣接支持細胞と接触してい る. この形態学的特徵は, I 型細胞が II 型細胞よりも， 隣接支持細胞からの酸素および, 栄養の供給を受けにく いことを示しているであろう．前庭感覚上皮の固定を行 なう場合に, しばしば, 死後変化あるいは, 固定の人工: 変化として, 光学顕微鏡による観察でも，II 型細胞の変 化より先に I 型細胞下部の萎縮がみられる場合が多いこ とは, おそらくこの形態学的特徵によると考えられる. したがつて，抗生物質障害などの場合にも，このI 型細 胞の形態学的脆弱性が重視されてよいと考えている，最 近, Winter $(1969)^{33}$ は, X線照射による前庭感覚上皮の 障害を研究し, II 型細胞が I 型細胞より障害されやすい ことを記載している，その原因は不明であり，したがつ て，I 型および，II型細胞の障害性の差異に関しては, 問題点が多数末解決のまま残されている.

\section{附図説明}

図 1 a 正常モルモット卵形のう感覚上皮表面像. 円形 の感覚細胞とそれを取囲む支持細胞のモザイク構造が 明瞭である. 感覚細胞の中で, 細胞表面の鋠染された I 型細胞（矢印）と，薄すく染まつたII 型細胞（点線 矢印）を明瞭に区別できる. 銀反応.

図 1 b SM (250mg $/ \mathrm{kg})$, 隔日， 8 周間投与後の卵形の 感覚上皮表面像. 感覚細胞の脱落が著明であり，肥大 
した支持細胞により㯰換されている，残存している感 覚細胞 (点線矢印) は, II 型細胞である. 銀反応.

図 2 a 正常モルモット半規管膨大部稜感賞上皮の全体 取出し標本. 感覚細胞のみが染色されており, 中心部 には大きな感覚細胞が粗に存在するのに対し, 辺縁部 では，小さな感覚細胞が密に存在するのを認める。コ 八ク酸脱水素醉素染色.

图 2 b SM $(250 \mathrm{mg} / \mathrm{kg})$ ，隔日， 4 週間投与後の半規管 膨大部稜感覚上皮の全体取出し標本. 中心部の障害が 著明にみられる.コハク酸脱水素酵素染色.

图 3 8 正常モルモット球形のら感覚上皮の全体取出し 標本.ほぼ中線を形成する Striola の中で，大きな 感覚細胞は浱染され，全体として，Striola の存在部位 が明瞭に認められる.コハク酸脱水素醭素染色.

图 3 b SM $(250 \mathrm{mg} / \mathrm{kg})$ ，隔日， 8 週間投与後の球形の う感賞上皮の全体取出し標本. I 型細胞は全て消失 し，わずかに少数の II 型細胞が散在している．Striola 前上部（矢印）の消失が認められるが, Striola 内の小 型の II 型細胞および，その他の辺縁部の II 型細胞に関 しては, 部位的な障害の差はあまり見られない.コ八 ク酸脱水素酵素染色.

\section{文献}

1) Endström, H., Ades, H.W., and Anderson, A.: Structural pattern of the organ of Corti. Almqvist \& Wiksell, Stockholm, 1966.

2) Lindeman, H.H.: Studies on the morphology of the sensory regions of the vestibular apparatus. Ergebn. Anat. u. Entwickl gesch. 42; 1 (1969).

3 ) Winter, F.: X-ray irradiation of the inner ear of the guinea pig. Acta Otolaryng. (Stockh.), 68, 514 (1969).

4 ) Lindeman, H.H.: Regional differences in sensitivity of the vestibular sensory epithelia to ototoxic antibiotics Acta Otolaryng. (Stockh.), 67, 177 (1969).

5 ) Watanuki, K., K. Karvamoto and S. Katagiri: Surface structure of the ampulla of the semicircular canal in the guinea pig. Pract. oto-rhino-laryng. (Besel), 32, 137 (1970).

6) Watanuki, K.: Some morphological observations of Reissner's membrane. Acta Otolaryng. (Stockh.), 66, 40 (1968).

7 ) Barka, T., and Anderson, P.J.: Histochemistry. Harper \& Row, New York, (1963).
8) Voit. M.: Zur Frage der Verästelung des Nervus acusticus bei den Säugetieren. Anat. Anz., 31 635 (1907).

9) Hawkins, J.E. Jr.: Disturbances of vestibular functions produced in animals by streptomycin. Federation Proceedings, 6, 1 (1947).

10) Hawkins, J.E. Jr., and Lurie, M.H.: The ototoxicity of streptomycin. Ann. Otol., 61 ; 789 (1952).

11) Winston, J., Lewery, F.H., Parentean, A., Mardem, P.A., and Cramer, F.B.: An experimental stu$\mathrm{dy}$ of the toxic effects of streptomycin on the vestibular apparatus of the cat. Ann. Otol., 57, 738 (1948).

12) Causse, $R .:$ Action toxique vestibulaire et ccchlaire de la streptomycine au point de vue experimental. Ann. Otolaryng. (Paris), 66, 518 (1949).

13) Ruedi, L., Furrer, W., Luthy, F., Nager, G., and Tschirren, B.: Further observations concerning the effects of streptomycin and quinine on the auditory organ of guinea pigs. Laryngoscope, 62, 333 (1952).

14) Ruedi, L.: Therapeutic and toxic effects of streptomycin in otology. Laryngoscope, 61, 613 (1951).

15) Christensen, E., Hertz, H., Riskaer, N., and Vrajensen, G.: Histological investigations in chronic streptomycin poisoning in guinea pigs. Ann. Otol., 60, 343 (1951).

16) Berg, K.: The toxic effect of streptomycin on the vestibular and cochlear apparatus. Acta Otolaryng. (Stockh.) Suppl. 97, 1 (1951).

17) Lurie, M.H.: The ototoxicity of drugs. Trans. Amer. Acad. Ophth. \& Otolaryng., 59, 111 (1955). 18) Schuknecht, H.F.: Ablation therapy in the management of Meniere's disease. Acta Otolaryng.(Stockh.) Suppl. 132, 1. (1957).

19) McGee, T.M., and Olszewski, J.: Streptomycin sulfate and dehydrostreptomycin toxicity. Archy. Otolaryng., 75, 295 (1962).

20) Wersäll, J., and Hawkins, J.E. Jr.: The vestibular sensory epithelia in the cat labyrinth and their reactions in chronic strepuomycin intoxication. Acta Otolaryng. (Stockh.), 54, 1 (1962).

21) Duvall, A.J., and Wersäll, J.: Site of action of streptomycin upon inner ear sensory cells. Acta Oto laryng. (Stockh.), 57, 581 (1963). 
22) Spoendlin, H.: Zur Ototoxizität des Streptomyzins. Pract. oto-rhino-laryng. (Basel), 28, 305 (1966).

23) Igarashi, M., Mcleod, M.E., and Graybiel, A.: Clinical pathological correlations in squirrel monkeys after suppression of semicircular canal function by streptomycin sulfate. Acta Otolaryng.(Stockh.) Suppl. 214, 1 (1966).

24) Nagaba, M.: Electron microscopic study of semicircular canal organs and otolith organs of squirrel monkeys after administration of streptomycin sulfate. Acta Otolaryng. (Stockh.), 66, 541 (1968).

25) Lange, G.: Die quantitative Auswertung von Streptomycinschäden des vestibulären Sinnesepithels beim Meerschweinchen mit Hilfe des Cytovestibulogramms und der calorischen Erregbarkeitsprüfung. Arch. Ohr. Nas. u. Kehlk. Heilk., 192, 249 (1968).

26) Farkashidy, J., Block, R.G., and Bryant, T.D.R.: The effect of kanamycin on the internal ear. Laryngoscope, 73, 713 (1963).

27) Kanda, T., and Igarashi, M.: Ultrastructural changes in vestibular sensory endorgans after viomyc $n$ sulfate intoxication. Acta Otolaryng. (Stockh.), 68, 474 (1969).

28) Werner, C.F.: Die Differenzierung der Maculae im Labyrinth, insbesondere bei Säugetieren. Z. Anat. Entwiokl. Gesch., 99, 696 (1966).

（原稿受付 昭和46，1，28日） 


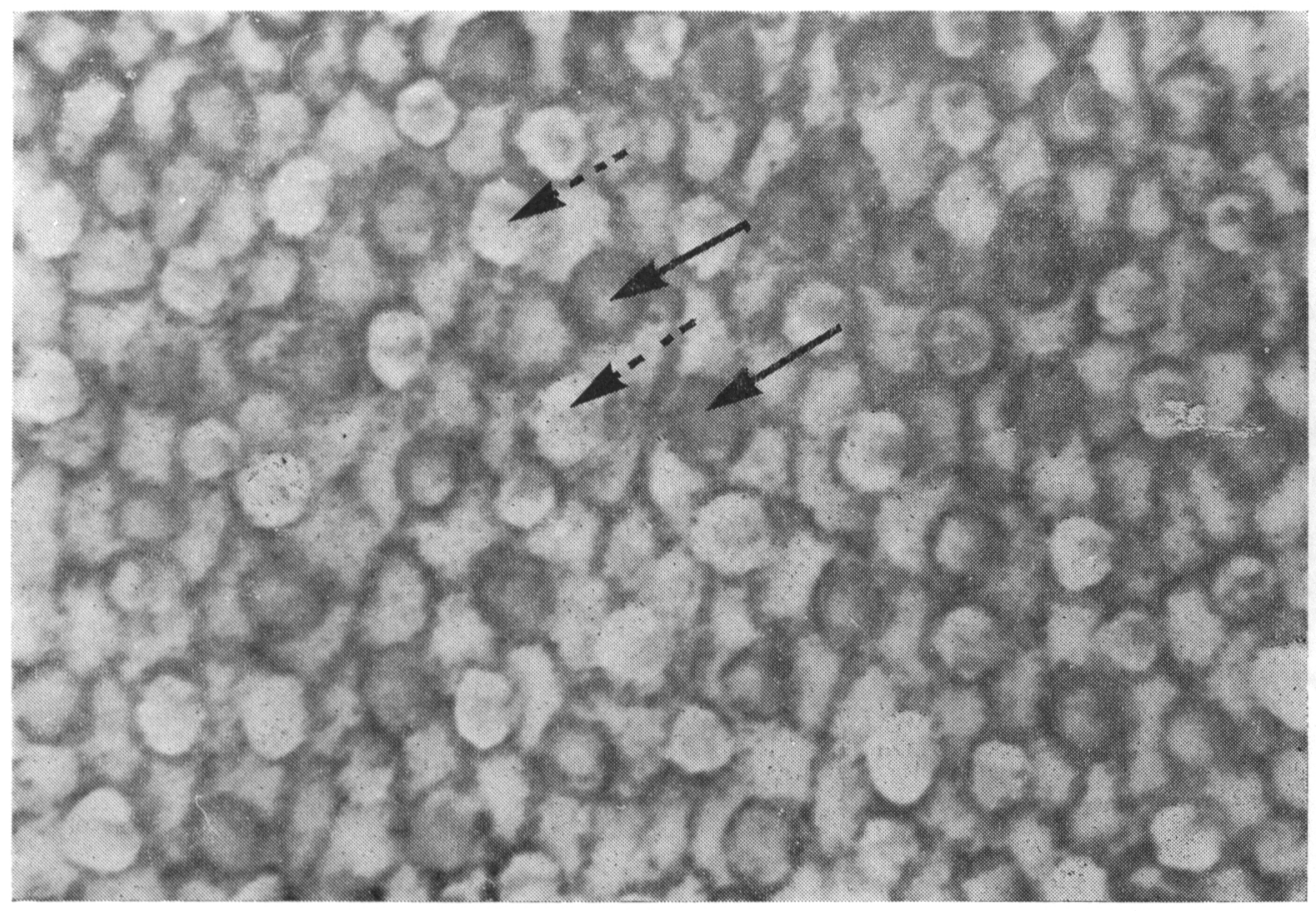

図 $1 \quad$ a

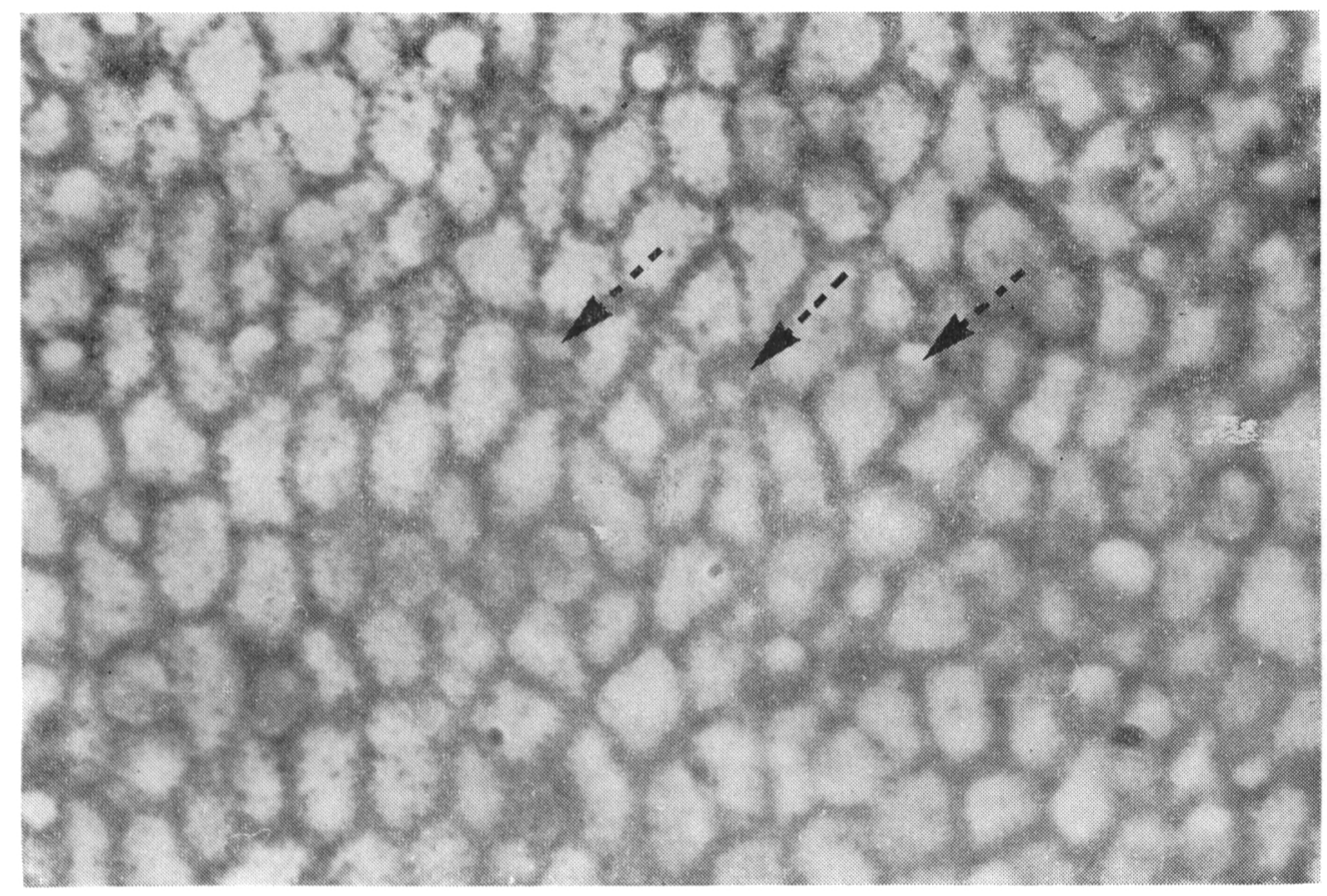

図 1 b 


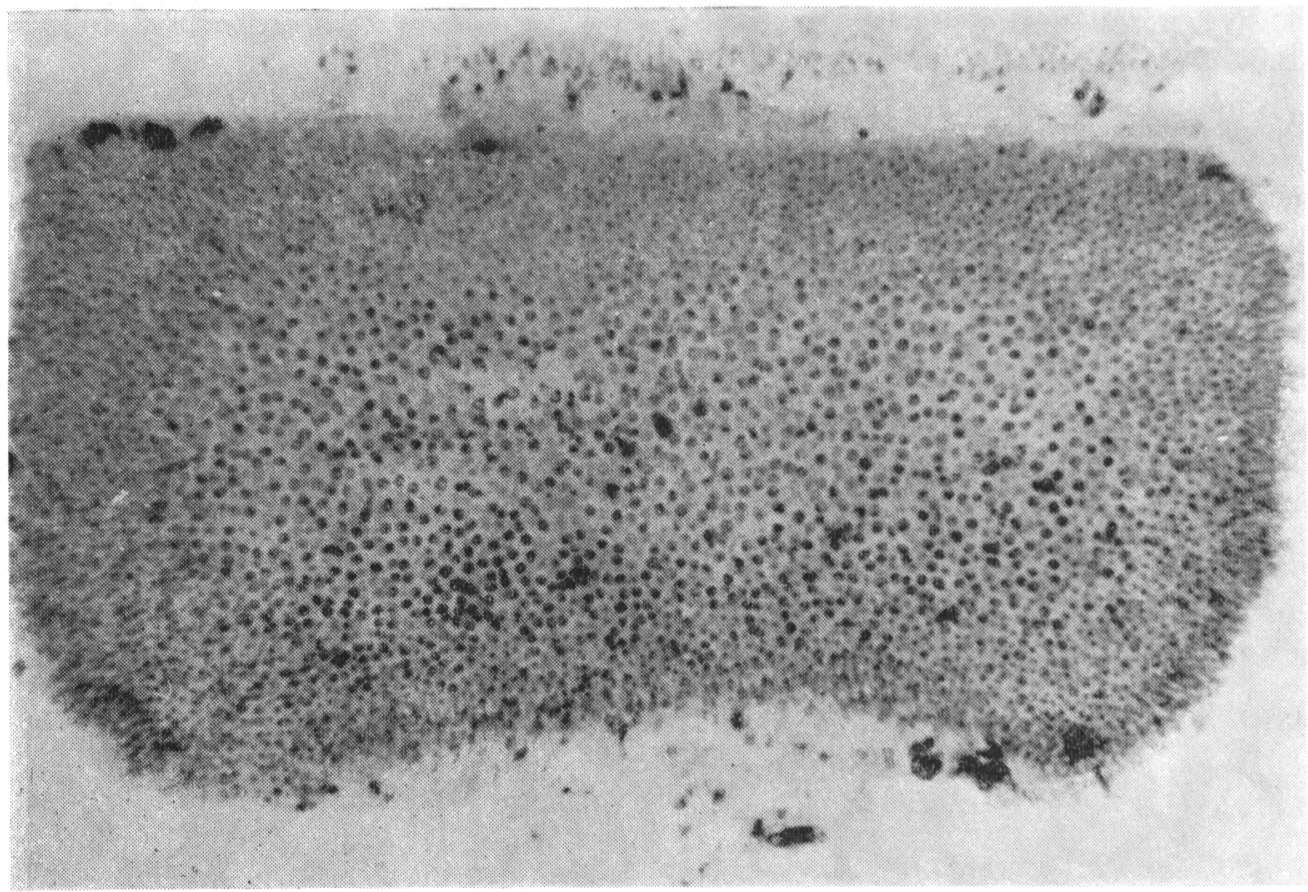

図 2 a

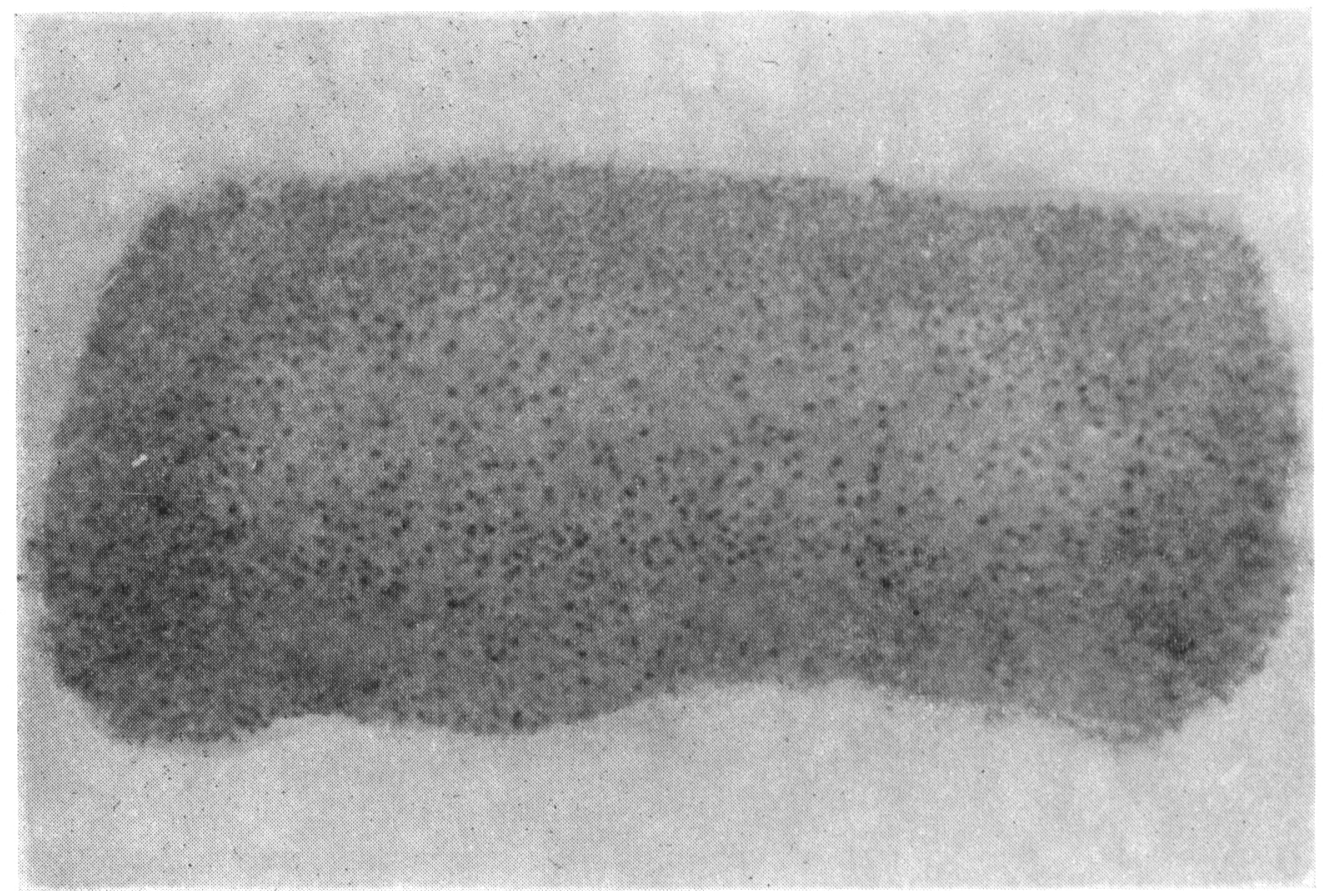

図 2 b 


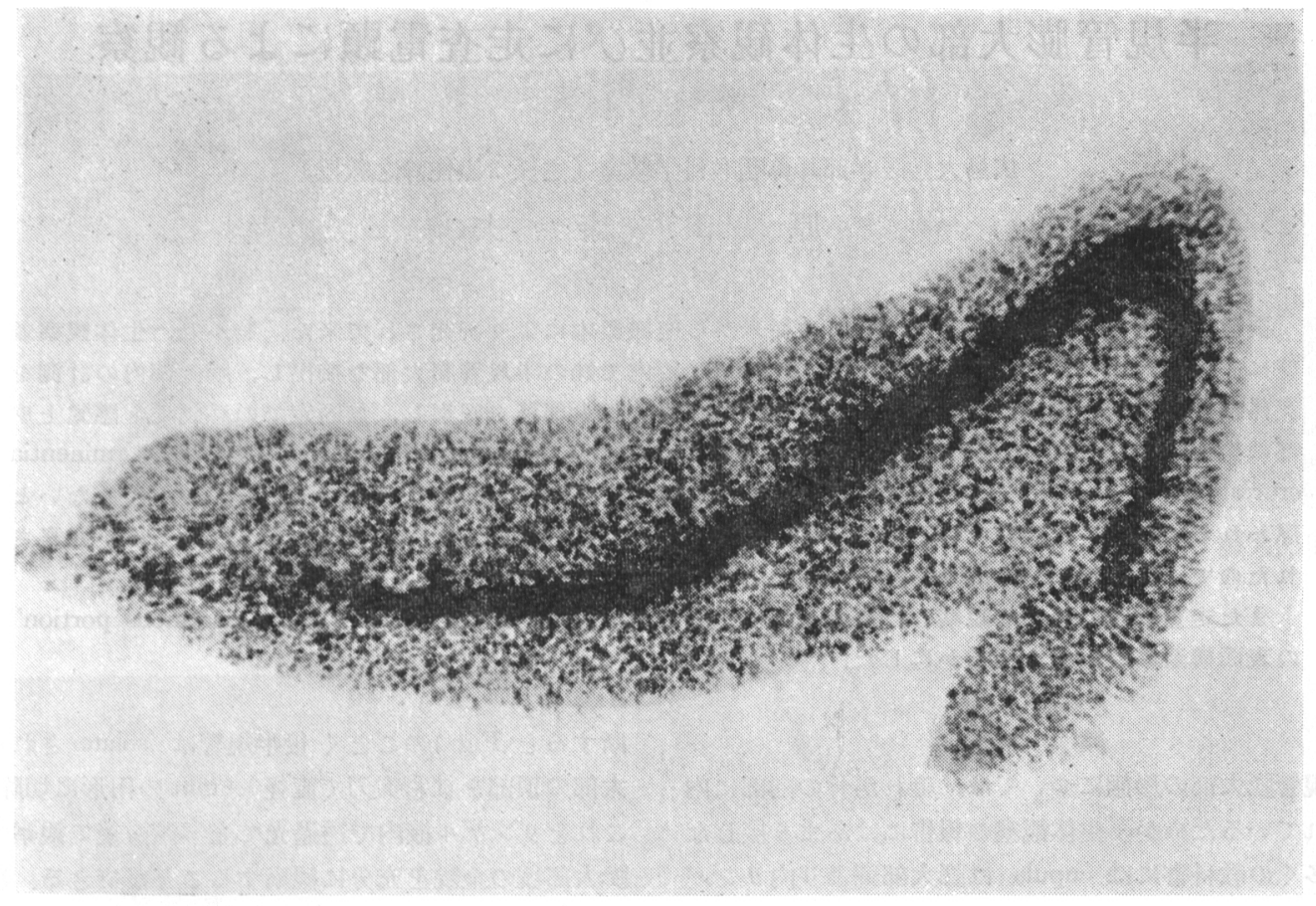

図 $3 a$

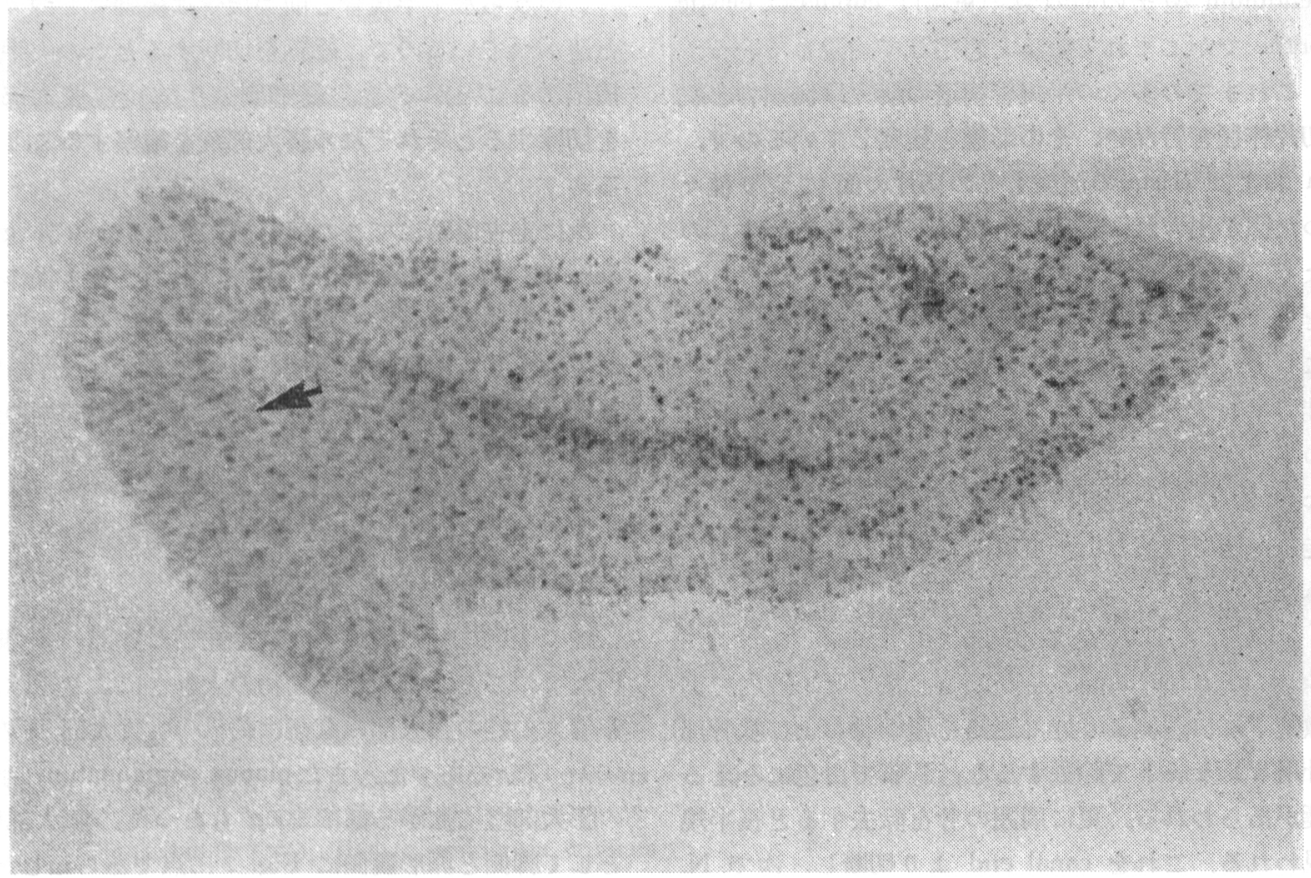

